\title{
PENERAPAN CSR (CORPORATE SOCIAL RESPONSIBILITY) MELALUI SINERGITAS ANTARA SEKOLAH MENENGAH KEJURUAN (SMK) DENGAN PENGRAJIN KERIS DI KABUPATEN SUMENEP
}

\author{
Bagus Ananda Kurniawan \\ Prodi Administrasi Publik, Fakultas IImu Sosial Dan Ilmu Politik, \\ Universitas Bhayangkara Surabaya \\ Email : bagusanandakurniawan@gmail.com
}

\begin{abstract}
ABSTRAK
Permasalahan pengangguran di Indonesia tiap tahun mengalami peningkatan. Pengangguran terbuka didominasi oleh pengangguran usia muda. Jawa Timur menjadi Propinsi dengan jumlah pengangguran terbesar ke-3 setelah Jawa Barat dan DKI Jakarta. Sumenep menjedi salah satu penyumbang jumlah pengangguran di Pulau Madura. Berdasarkan data yang diperoleh Hingga pertengahan 2014, angka pengangguran di Sumenep masih tinggi. Beberapa perusahaan maupun instansi pemerintahan belum bisa menyerap tenaga kerja secara memadai. Terbukti, jumlah pengangguran hingga sekarang mencapai 23.618 jiwa. Data Dinas Tenaga Kerja dan Transmigrasi (Disnakertrans), dari 40.762 jiwa pencari kerja (pencaker), yang terserap hingga Juli 2014 hanya sebanyak 17.144 jiwa. Jadi, masih tersisa 57,94 persen pencaker yang masih mengganggur. Hal ini sangat bertolak belakang dengan setting awal SMK yang disiapkan untuk siap kerja sesuai dengan kompetensi jurusan dan lapangan kerja yang ada. Beberapa hal yan menyebabkan lulusan SMK tidak mendapatkan pekerjaan antara lain, kurangnya kerjasama dalam hal publikasi antara pihak Sekolah Menengah Kejuruan (SMK) dan perusahaan, tidak adanya sinergi antara pemerintah perusahaan, SMK, dan Dinas maupun para pelaku UKM pengrajin Kabupaten Sumenep terkait dalam pencegahan meningkatnya jumlah pengangguran, serta tidak sesuainya kompetensi yang dimiliki oleh lulusan SMK dengan tenaga yang dibutuhkan oleh perusahaan. Penerapan CSR (Corporate Social Responsibility) melalui Sinergitas Antara Sekolah Menengah Kejuruan (SMK) Dengan Pengrajin Keris diharapkan akan mampu menekan jumlah pengangguran khususnya usia muda di Sekolah Menengah Kejuruan (SMK)

Terdapat lima langkah dalam pelaksaan penerapan CSR ini, langkah-langkahnya dimulai dengan Pembentukan program oleh pemerintah Kabupaten Sumenep untuk siswa SMK ada dua berupa business plan competition menggandeng Kelompok UKM pembuatan Keris Di kabupaten Sumenep. Selanjutnya adalah tahap sosialisasi ke tiap-tiap SMK mengenai program yang dicanangkan pemerintah.Kabupaten Sumenep dalam pelaksanaannya nanti setelah melewati tahap seleksi proposal bagi Kelompok UKM pembuatan Keris yang mengajukan proposal dan pendataan jumlah siswa yang akan di arahkan dan di fokuskan untuk membantu Kelompok UKM pembuatan Keris di Kabupaten Sumenep. pendampingan oleh Kelompok UKM pembuatan Keris di Kabupaten Sumenep langsung serta kontrol dari pemerintah dilakukan guna kelancaran program ini. sehingga nantinya dapat menghasilkan ouput berupa hasil didikan program pengembangan kewirausahaan sebagai bentuk awal atau perintis kelompok UKM Pembuatan Keris di Kabupaten Sumenep.
\end{abstract}


Keyword: CSR, SMK, sinergitas, Pengrajin Keris di Kabupaten Sumenep

\section{ABSTRACT}

The problem of unemployment in Indonesia each year has increased. Open unemployment is dominated by youth unemployment. East Java Province with the number of unemployed become the 3rd largest after West Java and Jakarta. Sumenep menjedi one contributor to the number of unemployed in the island of Madura. Based on data obtained As of mid-2014, the unemployment rate is still high in Sumenep. Several companies and government agencies have not been able to adequately absorb labor. Evidently, the number of unemployed up to now reaches 23618 inhabitants. Data Manpower and Transmigration (Manpower), of 40762 inhabitants job seekers (pencaker), which absorbed until July 2014 just as much as 17 I44 inhabitants. Thus, the remaining 57.94 per cent pencaker are still unemployed. This is contrary to the initial setting SMK prepared to be ready to work according to the department and the competence of existing jobs. Some things yan lead to vocational school graduates do not get jobs, among others, the lack of cooperation in terms of publications between the Vocational High School (SMK) and the company, the lack of synergy between government enterprises, vocational, and Office as well as SMEs craftsmen Sumenep involved in prevention increased the number of unemployed, as well as the incompatibility of competency of vocational graduates with the power needed by the company. Implementation of CSR (Corporate Social Responsibility) through Synergy Between Vocational High School (SMK) With Custom Kris is expected to be able to reduce the number of unemployed, especially young in vocational schools (SMK)

There are five steps in the implementation of the application of this CSR, the steps initiated by the Establishment of the program by the government of Sumenep for vocational students there are two in the form of a business plan competition took groups of SMEs of making Keris In Sumenep regency. Next is the stage of socialization into each vocational program launched on pemerintah.Kabupaten Sumenep in practice later after passing the stage of selection of proposals for SME groups that submitted proposals Keris-making and data collection number of students who will be directed and focused to help groups of SMEs of making Keris in Sumenep. mentoring by a group of SMEs manufacture Keris in Sumenep direct and control of the government done to the smooth running of this program. so that later can produce output in the form of education results of entrepreneurship development program as a form of early or pioneer group of SMEs Making Keris in Sumenep.

Keywords: CSR, SMK, synergy, Craftsman Keris in Sumenep

\section{PENDAHULUAN}

Pengangguran seringkali menjadi masalah dalam perekonomian sebuah negara karena dengan adanya pengangguran, produktivitas dan pendapatan masyarakat akan berkurang sehingga dapat menyebabkan timbulnya kemiskinan dan masalah-masalah sosial lainnya. Pada kenyataannya pengangguran terbuka atau terdidik (intelektual) di Indonesia juga terus mengalami peningkatan sejak beberapa tahun terakhir, sementara jumlah penganggur tidak terdidik makin turun. Jumlah penganggur usia muda (15 tahun-24 tahun) masih mendominasi jauh 
lebih banyak dibandingkan dengan penganggur dewasa. Kaum muda yang menganggur juga tidak mendapatkan kesempatan kerja yang memadai, sehingga tidak mampu mengembangkan kemampuan. Yang menjadi permasalahan dalam bidang ketenagakerjaan untuk kaum muda di Indonesia, adalah kesempatan kerja yang lebih luas. Sejumlah hal yang dapat dilakukan antara lain mengaktifkan kembali sekretariat jejaring tenaga kerja muda Indonesia dan memperkuat kerja sama di antara pemegang kepentingan, serta memasukkan isu ketenagakerjaan kaum muda ke dalam kebijakan pemerintah.Jumlah pengangguran di Jawa Timur pada tahun 2008-2012 mencapai 1,2 juta orang, dengan jumlah tersebut Jawa Timur menduduki peringkat ketiga dalam jumlah pengangguran terbesar setelah Jawa Barat 3,9 juta orang dan DKI Jakarta 2,8 juta orang. Dari jumlah itu, $35 \%$ di antaranya berusia antara 18 hingga 30 tahun, $15 \%$ penganggur berusia 30 hingga 45 tahun. peningaktan angka pengangguran yang terjadi diahir tahhun 2013 disebabkan tingkat pendidikan yang terlalu rendah, kebanyakan masyarakat Sampang yang tidak melanjutkan kejenjang yang lebih tinggi. Teguh Waluyo, Kasi Penempatan Dan Perluasan Tenaga Kerja Dinsosnakertrans menjelaskan bahwa peningkatan pengagguran di Madura, khususnya di Sampang karena lapangan kerja yang kecil belum ada yang menengah keatas, dan folume kelulusan tiap tahunnya sangat banyak. "Dinsosnakertrans bisanya hanya menyalurkan tenaga kerja. persoalan yang terjadi setiap tahun pada ketenagakerjaan di Jawa Timur adalah, jumlah angkatan kerja baru jauh lebih besar di banding pertumbuhan lapangan kerja produktif, dan rendahnya investasi baru (www.surya.co.id).

Dinas Tenaga Kerja dan Transmigrasi Kabupaten Sumenep, Jawa Timur, mencatat hampir 80 persen, atau 32.946 orang dari jumlah pengangguran di daerah itu merupakan usia produktif antara 20 tahun hingga 35 tahun. Mereka mayoritas lulusan Sekolah Menengah Atas maupun Sekolah Menengah Kejuruan (SMK) bahkan sarjana strata satu. Jika pertumbuhannya tidak ditekan, masalah ini akan menjadi ancaman serius Program pelatihan keterampilan dan kursus yang dilaksanakan tiap tahun, termasuk pula program bantuan modal usaha produktif belum menjadi solusi yang tepat karena masih terbentur minimnya anggaran yang disediakan pemerintah daerah. Hal ini mengindikasikan bahwa sangat bertolak belakang sekali dengan lulusan SMK yang kompetensi dasarnya memang lebih ditonjolkan dalam pendidikan keterampilan untuk bisa diaplikasikan dalam dunia kerja agar siap kerja, tetapi terjadi fakta yang berbeda di Surabaya. Dimana tingkat pengangguran justru lebih banyak berasal dari tamatan pendidikan menengah tersebut. Ini yang ditenggarai menjadi penyebab tingginya jumlah pengangguran muda di Surabaya khususnya SMK. Di tengah SMK yang sedang naik daun pada tingkat pendidikan menengah di Indonesia, harus diakui, belum semua SMK mampu menyiapkan lulusan yang adaptif dengan dunia kerja. Perusahaan-perusahaan dan industri mengeluhkan sulitnya mendapat teknisi tingkat menengah sesuai standar. Padahal, peluang kerja terbuka di dalam dan luar negeri, yang tidak terpenuhi karena lulusan yang ada belum mampu mencapai kompetensi yang dibutuhkan. Kenyataan menunjukkan tingginya ketimpangan kualitas pendidikan di Indonesia, termasuk di SMK. Tidak semua SMK benar- benar mampu menyediakan bengkel atau laboratorium kerja yang layak dan modern atau membangun kerja sama kuat dengan dunia kerja.

Kurangnya publikasi ataupun kerjasama dari pihak perusahaan terhadap sekolahsekolah menengah kejuruan yang ada di Surabaya diduga yang menjadi faktor penyebab banyaknya lulusan dari sekolah 
menengah tersebut kesulitan untuk mencari link pekerjaan. Karena kompetensi lulusan SMK yang tidak sesuai dengan kebutuhan perusahaan yang menjadi alasan perusahaanperusahaan tidak banyak menyerap tenaga kerja dari lulusan tersebut. Sangat disayangkan, dimana ada ribuan unit usaha, ratusan perusahaan, instansi pekerjaan lainnya tetapi masih banyak pengangguran dimanamana (www.rakyatmerdeka.co.id). Untuk itu dengan kontrol pemerintah melalui program untuk menekan jumlah angka pengangguran terbuka di Surabaya. Melalui sebuah strategi atau konsep yang menjadikan semua aktor (dinas pendidikan, dinas koperasi dan UKM, perusahaan, UKM, dan SMK) untuk bersinergi dalam merancang suatu program guna meminimalisir tingginya tingkat pengangguran Iulusan SMK di Surabaya.

Ekonomi kreatif adalah sebuah konsep di era ekonomi baru yang mengintensifkan informasi dan kreativitas dengan mengandalkan ide dan pengetahuan dari sumber daya manusia sebagai faktor produksi yang utama. Konsep ini biasanya akan didukung dengan keberadaan indnstri kreatif yang menjadi pengejawantahannya. Seiring berjalannya waktu, perkembangan ekonomi sampai pada taraf industri kreatif setelah beberapa waktu sebelumnya, dunia dihadapi dengan konsep ekonomi informasi yang mana informasi menjadi hal yang utama dalam pengembangan ekonomi. Kabupaten Sumenep juga memiliki potensi industri kerajinan yang bernilai sejarah dan turun-temurun, yaitu kerajinan keris. Industri ini terkonsentrasi di Desa Aeng Tongtong dan Desa Palongan Kec. Bluto. Ada sekitar 187 unit usaha dan menyerap tenaga kerja sebanyak 347 orang dalam memproduksi keris ini. Pangsa pasar yang tersedia adalah di Yogyakarta, Solo, Jakarta, Bali, dan juga ke luar negeri. Sebagai perhargaan pada kreatifitas para mpu di Sumenep, Bupati Sumenep, A. Busyro Karim, mencanangkan Kota Sumenep sebagai keris, dan sekaligus peresemian monumen keris yang terletak diujung barang Jl. Diponegoro Sumenep, atau dikenal pèlar bârâ' (pilar dibarat kota)

Perbedaan bentuk yang dimaksudkan dalam penjelasan diatas adalah perbedaan pada bagian "sor-soran". Umumnya ujung pada keris Madura berukuran lebih pendek bila dibandingkan dengan ujung pada keris Jawa. Hingga jika ditarik garis vertikal sampai ujung ganja membentuk sebuah pola yang agak kaku dan oleh masyarakat Madura disebut sebagai pola noron pjan seperti yang tertera pada (gambar dibawah ini)

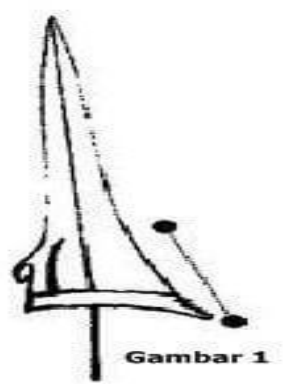

Nama ricikan keris Madura banyak memiliki persamaan dengan nama-nama ricikan keris Jawa. Penamaan pada ricikan keris Madura pada akhirnya menimbulkan kesan bahwa nama ricikan keris Madura berasal dari bahasa Jawa yang di Madura-kan, misalnya Gonjo Madura-nya ganca, peksi Madura-nya pakse pucuk Madura-nya pamoco k greneng Madura-nya garining.

Sedangkan nama ricikan yang berasal dari bahasa Madura asli diantaranya: Keloran (sogokan), pejetan (papakang), koko macan (kembang kacang), bubung (ada-ada), batton (gusen). Selain itu, dikenal juga sebutan pang bar at dalam (bilah bagian dalam) dan pang bar at luar (bilah bagian luar) 


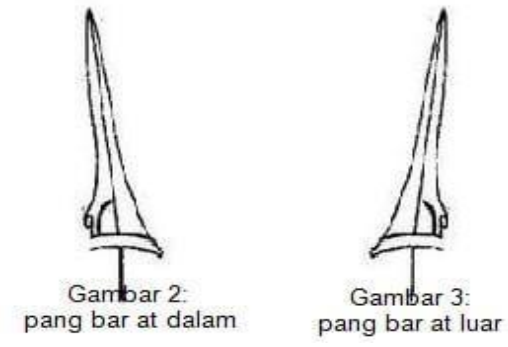

Sebagian masyarakat mempercayai bahwa sebuah keris harus lebih banyak dan lebih bagus pamornya dibagian pang barat dalam-nya dari pada pang barat luar, mereka beranggapan bahwa pang barat dalam adalah gambaran masa depan sedangkan pang barat luar adalah gambaran keadaan kita pada masa sekarang. Dikenal pula istilah ajub dalam yaitu pamor yang berada di ujung keris pang barat dalam terlihat lebih menonjol dari pada pamor yang berada di ujung pang barat luar. Ini juga dipercaya bahwa si pemilik keris tersebut tidak akan kedahuluan lawannya dalam peperangan dan lain-lain. Sedangkan ajub luar adalah sebaliknya. Desa Aeng Tong Tong adalah satu-satunya daerah penghasil dan pembuat keris yang terdapat di Pulau Madura yang sampai bertahan dari Jaman Kerajaan Sumenep sampai sekarang, Desa Aeng Tong Tong sendiri terletak di sebelah barat laut Kecamatan Saronggi dan masih masuk kawasan Kecamatan Saronggi.

Dengan membuat program pembelajaran wirausaha untuk siswa SMK bekerjasama dengan para pengrajin keris di Kabuypaten Sumenep. Disini penulis menawarkan konsep pada pemerintah untuk memaksimalkan fungsi Corporate Social Responsibility (CSR) perusahaan terhadap lingkungan terutama bidang pendidikan ketrampilan pembuatan keris di Kabupaten Sumenep. Didalam prakteknya, penerapan CSR diharapkan mampu membantu program perencanaan wirausaha mandiri yang dilakukan disesuaikan dengan kemampuan masing-masing perusahaan dan kompetensi sekolah maupun juga para pengrajin Keris Di Kabupaten Sumenep. Idealnya terlebih dahulu dirumuskan bersama antara 3 pilar yakni dunia usaha Keris di Kabupaten Sumenep, Pemerintah Daerah Kabupaten Sumenep dan SMK di Kabupaten Sumenep. Kemudian dilaksanakan sendiri oleh masing-masing industri kreatif pembuatan Keris ini. Dengan demikian untuk memaksimalkan pelaksanaan CSR perusahaan dilakukan melalui program ini.

Komitmen semua aktor tersebut sangat mendukung kelancaran pelaksanaan program dari dinas pendidikan yang berkesinambungan untuk mencapai hasil berupa peningkatan daya saing SMK. Dengan membekali siswa untuk tidak mencari pekerjaan sebagai orientasi setelah lulus tetapi bisa untuk melakukan wirausaha cara pembuatan Keris di Kabupaten Sumenep. Sehingga nantinya dapat meminimalisir angka pengangguran muda khususnya SMK di Kabupaten Sumenep. Berdasarkan pemaparan latar belakang permasalahan diatas maka penulis tertarik untuk membuat karya tulis ilmiah dengan judul Penerapan CSR (Corporate Social Responsibility) melalui Sinergitas Antara Sekolah Menengah Kejuruan (SMK) Dengan Pengrajin Keris di Kabupaten Sumenep.

\section{METODE PENELITIAN}

Berdasarkan pada permasalahan yang diangkat didalam penulisan ini maka metode penelitian yang digunakan adalah dengan pendekatan deskriptif kualitatif, yaitu suatu metode dalam meneliti status seseorang, suatu objek, suatu situasi atau kondisi sistem pemikiran.

\section{HASIL DAN PEMBAHASAN}

Perusahaan yang bergerak dibidang pengrajin Keris atau Industri Kreatif di Desa Desa Kabupaten Sumenep yang menjadi salah satu alternatif tujuan siswa SMK setelah lulus, dan SMK itu sendiri sebagai institusi yang 
mencetak tenaga-tenaga ahli dan diarahkan ikut serta membuat kerajinan Keris maupun bekerjasama dengan Kelompok - kelompok Pengrajin Keris di Kabupaten Sumenep untuk menanggulangi masalah tersebut. Sinergitas antar aktor setidaknya akan mampu memberikan sebuah solusi alternatif, sebuah konsep atau program baru yang mampu memfasilitasi lulusan SMK, sehingga mampu untuk mengembangkan diri. Karena pada dasarnya lulusan SMK dicetak untuk menjadi manusia yang siap kerja.

Peran Pemerintah dalam sinergi ini adalah lebih kepada sebagai pemegang kontrol dan pengambil kebijakan yang harus dilakukan aktor yang lain secara bersama-sama sehingga tidak terjadi tumpang tindih kepentingan yang menyebabkan tidak berjalannya program yang nantinya akan dibentuk oleh pemerintah. Kontrol terhadap pelaksanaan CSR (Corporate Social Responsibility) dari perusahaan yang telah digandeng, Kelompok - kelompok Pengrajin Keris di Kabupaten Sumenep dan juga siswa SMK yang ada di Kabupaten Sumenep (masyarakat).

Tanggung jawab sosial (CSR) didefinisikan sebagai tanggung jawab sebuah organisasi atas dampak dari keputusan dan aktivitasnya terhadap masyarakat dan lingkungan, melalui perilaku transparan dan etis, konsisten dengan pembangunan berkelanjutan dan kesejahteraan masyarakat; memerhatikan harapan dari para pemangku kepentingan; sesuai hukum yang berlaku dan konsisten dengan norma-norma perilaku internasional; dan terintegrasi di seluruh organisai. Pada dasarnya kegiatan CSR sangat beragam bergantung pada proses interaksi sosial, bersifat sukarela didasarkan pada dorongan moral dan etika, dan biasanya melebihi dari hanya sekedar kewajiban memenuhi peraturan perundang-undangan (Undang-undang Nomor 40 Tahun 2007 tentang Perseroan Terbatas). Oleh karena itu, di dalam praktek, penerapan CSR selalu disesuaikan dengan kemampuan masingmasing perusahaan dan kebutuhan masyarakat. Idealnya terlebih dahulu dirumuskan bersama antara 3 pilar yakni dunia usaha, pemerintah dan masyarakat setempat dan kemudian dilaksanakan sendiri oleh masing-masing perusahaan (Koran Bisnis Indonesia, 2006).

CSR pada dasarnya mempunyai tujuan akhir yaitu Sustainable development (pembangunan yang berkelanjutan). Defenisi pembangunn berkelajutan menurut WCED: World Commission on Environment and Development adalah pembangunan yang dapat memenuhi kebutuhan saat ini dengan memberikan kesempatan yang sama bagi generasi mendatang untuk mempunyai kemampuan dalam memenuhi kebutuhannya sendiri.

Perusahaan melalui CSR-nya dapat membantu mengurangi kemiskinan dan pengangguran. Menurut Sachs dalam Radyati (2008) terdapat 6 modal utama yang tidak dimiliki masyarakat yang termiskin. Perusahaan dapat memilih jenis modal mana yang akan dijadikan target untuk diberi bantuan. Keenam modal tersebut antara lain, business, infrastructure, knowledge, public institutional, natural, and human.

Dalam kegiatan CSR untuk mengembangkan ekonomi perusahaan juga harus melibatkan komunitas. Melibatkan komunitas dalam meningkatkan ekonomi masyarakat artinya perusahaan secara aktif menggunakan sumber daya yang dimiliki untuk mendukung pengembangan ekonomi dan sosial dari komunitas melalui investasi langsung atau kebijakan perusahaan seperti local sourcing, partnership dan pendidikan, yang dapat menciptakan "modal komunitas" (community capital). (sumber: SustainAbility Ltd, 2002, dalam Radyati, 2008). Hasil 
Penelitian Kementrian Koperasi dan UKM bersama BPS menunjukkan bahwa proporsi pelaku UKM mencapai 99,98\%. Selain itu UKM merupakan sektor yang paling tahan menghadapi kondisi krisis ekonomi, sehingga secara umum perekonomian di Indonesia ditopang oleh keberadaan UKM. Berdasarkan fakta di atas, maka CSR untuk memberdayakan ekonomi Indonesia perlu juga bagi perusahaan untuk berkosentrasi pada pengembangan UKM (Radyati, 2008).

Dalam kegiatan CSR untuk mengembangkan ekonomi perusahaan juga harus melibatkan komunitas. Melibatkan komunitas dalam meningkatkan ekonomi masyarakat artinya perusahaan secara aktif menggunakan sumber daya yang dimiliki untuk mendukung pengembangan ekonomi dan sosial dari komunitas melalui investasi langsung atau kebijakan perusahaan seperti local sourcing, partnership dan pendidikan, yang dapat menciptakan "modal komunitas" (community capital). (sumber: SustainAbility Ltd, 2002, dalam Radyati, 2008). Hasil Penelitian Kementrian Koperasi dan UKM bersama BPS menunjukkan bahwa proporsi pelaku UKM mencapai 99,98\%. Selain itu UKM merupakan sektor yang paling tahan menghadapi kondisi krisis ekonomi, sehingga secara umum perekonomian di Indonesia ditopang oleh keberadaan UKM. Berdasarkan fakta di atas, maka CSR untuk memberdayakan ekonomi Indonesia perlu juga bagi perusahaan untuk berkosentrasi pada pengembangan UKM (Radyati, 2008).

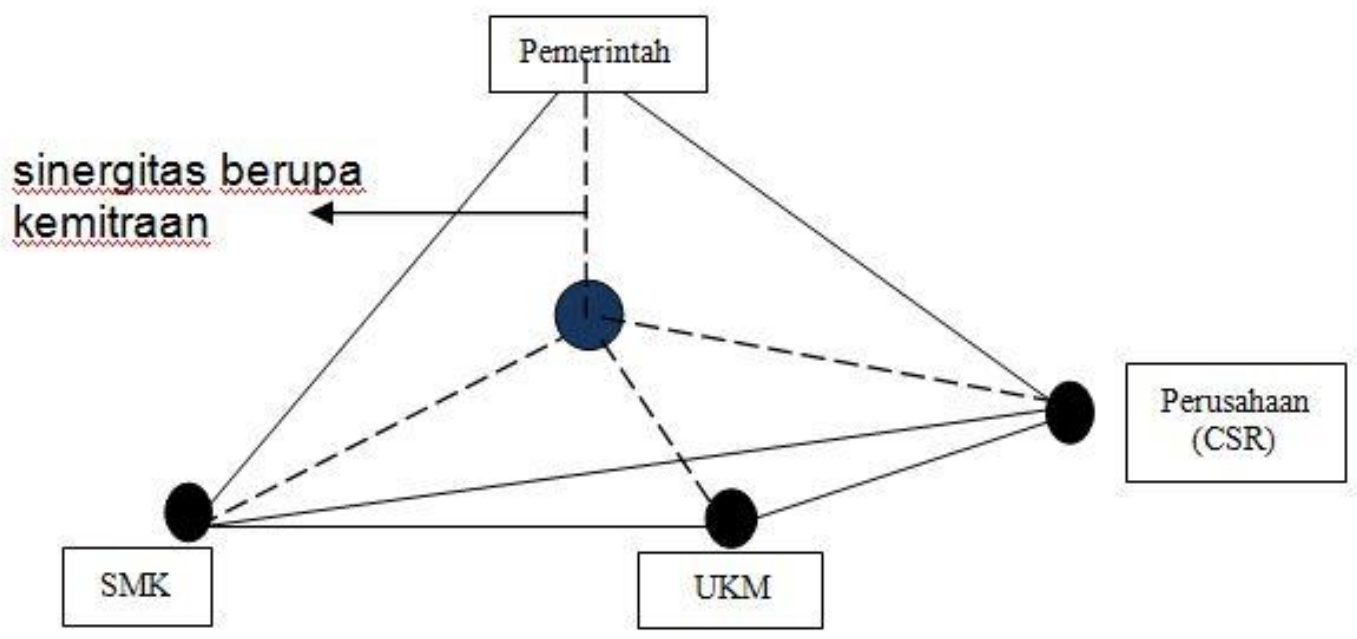

Gambar 2. Sinergitas antar aktor (Sumber: diolah Penulis)

Berbagai studi menunjukkan, keberhasilan program CSR selama ini justru terkait dengan sinergitas kerja sama perusahaan, masyarakat, dan pemerintah. Segitiga peran itu memungkinkan integrasi kepentingan atau program semua stakeholders pembangunan. Bahkan tidak jarang CSR menjadi semacam titik temu antara wilayah isu yang menjadi perhatian perusahaan, kepentingan riil masyarakat setempat, dan program pemda dalam kerangka pembangunan regional. Untuk Indonesia, pelaksanaan CSR membutuhkan dukungan pemerintah daerah, kepastian hukum, dan jaminan ketertiban sosial (www.surya.co.id). Adapun beberapa tahapan dalam pelaksanaan program ini, berikut penjelasan secara rinci untuk tahapan-tahapannya. 


\section{Pembentukan Program oleh Pemerintah Berupa Program Business Plan Competition dan Membentuk Jaringan Kemitraan}

Sebagai langkah awal pemerintah
Kabupaten Sumenep akan melakukan
pembentukan program dengan membentuk
Tim Pokja (kelompok kerja) yang melibatkan
dinas dan aktor terkait yang dalam hal ini
adalah Dinas Koperasi dan UKM, Dinas Pendidikan untuk Sekolah Menengah Atas (SMK) Kabupaten Sumenep, serta membentuk jaringan kemitraan dengan Kelompok UKM Pembuatan Keris Dikabupaten Sumenep yang telah ditunjuk oleh Pemerintah Kabupaten Sumenep, dan tentunya melibatkan perusahaan yang berminat membeli Keris dari Kelompok UKM pembuatan Keris Kabupaten Sumenep. Dalam pembentukan program ini akan ditentukan program Business Plan Competition antar Kelompok UKM pembuatan Keris Kabupaten Sumenep dengan menggandeng Sekolah Menengah Kejuruan (SMK) seluruh Kabupaten Sumenep sebagai tenaga untuk membuat Keris. Dengan harapan dapat memunculkan usaha-usaha baru yang nantinya apabila sudah terealisasi dapat mereduksi pengangguran usia muda di Kabupaten Sumenep. Business Plan ini akan menjadi pilot project sebagai langkah awal untuk menekan angka pengangguran usia muda di Kabupaten Sumenep. Dalam pembentukan program ini juga akan ditentukan mengenai ketentuan dan teknis pelaksanaan kegiatan. Program ini akan menyeleksi program business plan yang masuk, dan memilih lima terbaik yang masuk grand final dan selanjutnya akan dilakukan realisasi program business plan dengan memanfaatkan fasilitas CSR dari perusahaan yang ingin menampung, memasarkan dan membeli hasil pembuatan keris ini, program ini tidak berhenti sampai disitu, akan tetapi dari program yang direalisasikan akan diberi apresiasi berupa penghargaan business plan competition. Program ini akan dilakukan secara berkelanjutan. Dengan lama waktu kompetisi 2 tahun ( 1 tahun pelaksanaan program tahap I, 1 tahun pelaksanaan program tahap II) maka pemerintah Kabupaten Sumenep bekerjasama dengan salah satu media cetak dan elektronik sebagai pemantau pelaksanaan program dan media promosi program ini.

Sasaran untuk peserta program business plan ini adalah Kelompok UKM pembuatan Keris Kabupaten Sumenep dengan menggandeng siswa kelas 1 dan 2 SMK sebagai tenaga pembuatan Keris. Hal ini di ambil dengan mempertimbangkan kesiapan, keterbatasan waktu serta kesesuaian jangka waktu pelaksanaan program. Melalui program ini para siswa di SMK diharuskan untuk menjadi seorang wirausaha dengan membantu Kelompok UKM pembuatan Keris Kabupaten Sumenep, VP of finance, VP of $H R D$, production, $P R$ dan marketing yang dijabat oleh Kelompok UKM pembuatan Keris Kabupaten Sumenep dan siswa Semkolah Menengah Kejuruan (SMK) sendiri. Mereka harus melakukan market research untuk menyusun business plan dan strategi pemasaran seperti apa yang telah mereka tempuh dalam mata pelajaran kewirausahaan tingkat Sekolah Menengah Kejuruan (SMK). Dalam pembentukan program ini pemerintah bertindak sebagai kontrol dan fasilitator, pemerintah benar-benar menekankan mengenai pentingnya kegiatan ini dan juga komitmen dari aktor yang terlibat dalam tahap ini. Dalam tahap ini juga dibahas mengenai tujuan jangka pendek, menengah dan tujuan jangka panjang program ini. Tujuan program ini akan dijelaskan secara mendalam pada tahap pelaksanaan program. Dalam pembentukan program ini juga akan dibentuk tim independen dari pemerintah Kabupaten Sumenep sebagai tim yang akan melakukan monitoring dana 
evaluasi bersama dengan perusahaan selaku pengemban CSR. Monitoring dan evaluasi ini dimaksudkan agar program dapat berjalan dengan optimal. Sehingga partisipasi aktif aktor yang terlibat sangat mendukung program ini. Hasil dari program ini akan dijadikan evaluasi dan acuan untuk melakukan program sejenis untuk tahun-tahun berikutnya sehingga mampu menciptakan lapangan usaha baru dan unit usaha baru.

\section{Sosialisasi Program pada Seluruh Sekolah Menengah Kejuruan (SMK) di Kabupaten Sumenep}

Langkah selanjutnya adalah melakukan sosialisasi mengenai program yang digagas oleh Tim Pokja. Sosialisasi ini akan disampaikan melalui berbagai macam media, dari situs resmi pemerintah Surabaya, media elektronik lainnya dan media massa. Selain itu dari pihak yang mensosialisasikan, dalam hal ini adalah Dinas Pendidikan akan mengumpulkan seluruh Kepala Sekolah SMK seluruh Kabupaten Sumenep untuk meminimalisir terjadinya kesalahan informasi mengenai jalannya program. Tahap sosialisasi ini merupakan tahap yang paling penting, hal ini dikarenakan dari tahap inilah program ini akan dimulai. Pemerintah Kabupaten Sumenep harus mencanangkan program Pemberdayaan Kelompok UKM Pembuatan Keris Kabupaten Sumenep melalui fasilitasi Pengembangan Sarana Promosi Hasil Produksi Keris. Bentuk kegiatan ini dialokasikan untuk pelaksanaan inventarisasi potensi hasil produk bagi Kelompok UKM Pembuatan Keris Kabupaten Sumenep sebagai bahan fasilitasi jaringan promosi sebagai persiapan awal dalam mengikuti berbagai macam event pameran produk UKM Keris. Dampak dan hasil kegiatan ini memberikan wawasan dan pengalaman serta sebagai ajang study peningkatan kualitas produk sesama Kelompok UKM Pembuatan
Keris Kabupaten Sumenep dari berbagai jenis produk dan daerah Kabupaten/Kota lainnya.

Berbagai macam latar belakang Sekolah Menengah Kejuruan (SMK) di Kabupaten Sumenep juga dijadikan pertimbangan mengapa tahap sosialisasi ini sangat penting. Selain benar-benar untuk menumbuhkan apresisasi siswa SMK untuk berwirausaha dan sebagai tenaga pembuat Keris di Kabupaten Sumenep dengan Bekerjasama dengan Kelompok UKM pembuatan Keris di Kabupaten Sumenep. Tahap sosialisasi ini bertujuan untuk menghilangkan kesenjangan antar SMK dan Kelompok UKM pembuatan Keris di Kabupaten Sumenep. Sosialisasi program ini juga menginformasikan lebih detail tahap-tahap pelaksanaan program realisasi program business plan dari proses seleksi grandfinal, realisasi program hingga pelaksanaan program. Bentuk kegiatan Kerjasama antara Sekolah Menengah Kejuruan (SMK) dan Kelompok UKM pembuatan Keris Kabupaten Sumenep ini dialokasikan pada kegiatan guna terciptanya pengembangan pola - pola usaha dan Kelompok UKM pembuatan Keris Kabupaten Sumenep agar mampu meningkatkan pengelolan usaha yang produktif, dengan cara penataan/lay out pertokoan tempat pembuatan Keris dan penambahan alat pembuatan Keris. utamanya kesiapan dan Kelompok UKM pembuatan Keris Kabupaten Sumenep dalam memasuki pangsa pasar di sektor riil modern. Hasil dan dampak kegiatan ini adalah untuk tersalurnya jaringan pemasaran bagi pruduk hasil dan Kelompok UKM pembuatan Keris Kabupaten Sumenep yang memenuhi syarat kelayakan konsumsi dapat dipasarkan di Koperasi yang ada di Kabupaten Sumenep dan dipasarkan Keluar Kabupaten Sumenep.

\section{Proses Seleksi Proposal Program Business Plan Competition}


Setelah dilakukan sosialisasi, tahap berikutnya adalah melakukan proses seleksi yang bertujuan untuk menentukan rencana bisnis yang paling layak untuk direalisasikan sesuai dengan rencana awal dalam penentuan pembentukan program. Pemerintah Surabaya tetap berperan sebagai kontrol dalam proses penyelekseian ini. Sementara pihak yang terkait dalam pelaksanaan proses seleksi ini adalah dari Tim Pokja Kabupaten Sumenep sebagai penyeleksi masing-masing peserta dan Kelompok UKM pembuatan Keris Kabupaten Sumenep untuk menentukan peserta yang berhak untuk direalisasikan rencana bisnisnya. Tujuan dari proses seleksi ini diharapkan mampu memperoleh business plan yang sesuai, aplikatif dan dapat dipertanggungjawabkan pelaksanaannya. Proses seleksi ini akan memilih 5 program business plan yang layak untuk direalisasikan (grandfinal business plan competition)

\section{Pelaksanaan Program}

Sinergitas antara aktor dalam menerapkan program ini sangatlah penting, karena dengan begitu tujuan yang diharapkan akan maksimal. Adapun tujuan jangka pendek dalam kegiatan ini adalah sebagai pondasi awal pengenalan siswa Sekolah Menengah Kejuruan (SMK) dan Kelompok UKM pembuatan Keris Kabupaten Sumenep terhadap dunia usaha. Mereka disiapkan untuk bekerja untuk mengembangkan usaha yang sudah mereka rancang, konsisten dan berkomitmen untuk menjalankannya.. Dalam tujuan jangka pendek ini pelibatan UKM sebagai pendamping sangatlah penting.

Peran untuk memberikan pembinaan untuk menjadikan mereka tangguh berada pada tahapan ini. Tujuan jangka menengahnya adalah dapat dihasilkannya sebuah output berupa Rintisan dan Kelompok UKM pembuatan Keris Binaan Mandiri Kabupaten Sumenep dari business plan yang dikelola oleh siswa dan Siswa kelas 1 dan Kelas Sekolah Menengah Kejuruan (SMK) dan keberlanjutannya akan mampu menyerap tenaga kerja dari lulusan Sekolah Menengah Kejuruan (SMK) itu sendiri. Sehingga Siswa Kelas 1 dan Siswa Kelas 2 Sekolah Menengah Kejuruan (SMK) benar-benar dapat untuk bekerja sesuai dengan keahliannya. Sedangkan tujuan jangka panjangnya adalah terbentuknya dan Kelompok UKM-UKM pembuatan Keris Mandiri Kabupaten Sumenep baru yang akan mampu menyerap tenagatenaga Sekolah Mennegah Kejuruan (SMK) dengan pembinaan melalui antar aktor sejak dini. Pelaksanaan program ini terbagi menjadi dua tahapan, dimana tahapan-tahapan tersebut akan menentukan sejauh mana business plan mereka akan direalisasikan.

Pemerintah tetap memegang peran dalan mengontrol berjalannya program ini, sementara UKM akan berkonsentrasi untuk memberikan pembinaan pada para pelaksana untuk benarbenar menyiapkan business plan-nya. Kerjasama yang terjali Siswa Kelas 1 dan Siswa Kelas 2 Kelompok UKM pembuatan Keris Kabupaten Sumenep ini juga menanamkan jiwa wirausaha dan juga rasa tanggung jawab serta memiliki usaha ini. Karena, bagaimanapun juga program ini merupakan dari pemerintah yang nantinya akan diharapkan mampu untuk menekan angka jumlah pengangguran usia muda pada lulusan SMK. Dengan kontrol dari pemerintah, CSR Bantuan hibah/bantuan sosial diberikan kepada Kelompok UKM Pembuatan Keris Kabupaten Sumenep sebagai tambahan modal usaha yang memiliki kinerja baik. Pemerintah Kabupaten Sumenep terhadap UKM tidak hanya sebatas kata. Bank Jatim dan Bank Pekreditan Rakyat Syariah (BPRS) Bhakti Sumekar bisa sebagai alternatif lembaga penghimpun dana dan memberi nilai pinjaman ditambah hingga puluhan juta. Bank Jatim dan Bank Pekreditan Rakyat Syariah 
(BPRS) Bhakti Sumekar selalu membantu masyarakat yang membutuhkan modal untuk mengembangkan usaha. Karena ini, bagian dari salah satu misi Pemerintah Kabupaten Sumenep untuk memperkuat ekonomi masyarakat bawah khususnya Kelompok UKM pembuatan Keris Kabupaten Sumenep.

\section{a) Pelaksanaan program tahap I}

Pelaksanaan dari program ini merupakan pelaksanaan awal business plan. Siswa Kelas 1 dan Kelas 2 Sekolah Menengah Kejuruan (SMK) sudah mulai membantu mengerjakan Keris Kabupaten Sumenep dan ikut serta membantu memasarkan hasil pembuatan Keris berdasarkan rencana bisnis. Pada tahap ini lebih menekankan mengenai persiapan sebelum memulai program. Diantara persiapan yang dilakukan adalah menetapkan jumlah kebutuhan usaha, menetapkan standar kualitas produk yang akan dihasilkan, menjalin kerjasama dengan kelompok UKM pembuatan Keris Luar Kabupaten Sumenep (sebagai pendamping) jika ada dan jika tidak ada pemerintah Kabupaten Sumenep wajib mencarikannya, bagaimana menjalin kerjasama dengan pelanggan, dan konsumen, melakukan needs assessment sebagai upaya untuk memahami dan menanggapi kebutuhan mereka dengan harapan agar dapat menghasilkan kegiatan yang terfokus. Pelaksanaan program ini berjalan selama 1 tahun.

\section{b) Monitoring dan evaluasi program tahap I}

Evaluasi dilakukan secara berkala yang dilakukan oleh perusahaan, khususnya dari divisi CSR perusahaan yang menampung dan memasarkan produk hasil pembuatan Keris bersama tim independen bentukan pemerintah Kabupaten Sumenep sebagai kontrol kinerja (Tim Monev). Tidak sedikit perusahaan yang menampung dan memasarkan produk hasil pembuatan Keris yang melibatkan konsultan atau external expert untuk memberikan kritik atau masukan dan membantu melakukan perbandingan hasil dengan ukuran yang ditetapkan sendiri. Evaluasi dilakukan untuk memonitor apakah pelaksanaan persiapan program dilaksanakan sesuai dengan rencana atau tidak, dan apakah program mencapai target atau tidak. Hasil evaluasi harus dalam bentuk kualitatif dan kuantitatif sehingga dapat terukur dengan angka-angka. Pelaporan ini dilakukan 4 bulan sekali pada pelaksanaan program tahap 1. Pelaksana program kerjasama Siswa Kelas 1 dan Siswa kelas 2 Sekolah Menengah Kejuruan (siswa SMK) dengan Kelompok UKM Pembuatan Keris Kabupaten Sumenep melaporkan pada tim monev dan dari perusahaan yang menam[ung hasil produksi keris dan memasarkannya di Luar Kabupaten Sumenep. Laporan kegiatan ini juga akan dipublikasikan dalam sustainability report yang disusun atas dampingan UKM. Pemerintah Kabupaten Sumenep bisa mengadakan Bintek peningkatan pengawasan antara kerjasama Siswa Kelas 1 dan Siswa kelas 2 Sekolah Menengah Kejuruan (siswa SMK) dengan Kelompok UKM Pembuatan Keris Kabupaten Sumenep, dengan tujuan untuk meningkatkan pengelolaan usaha guna terciptanya kualitas produk agar mampu mengembangkan pemasaran dan mengadakan Pelatihan keterampilan bagi kerjasama ini. Upaya yang dilakukan Pemerintah Kabupaten Sumenep memasarkan produk hasil Keris juga menjalankan Bazar UKM Keris dengan maksud dan tujuan menambah pengalaman, wawasan serta berinteragsi langsung dengan konsumen bagi Kelompok UKM pembuat Keris di Kabupaten Sumenep.

Dalam monev I akan ditentukan juga program business plan yang layak untuk dilanjutkan atau tidak, berdasarkan peninjauan laporan. Bagi program business plan yang tidak layak maka program tersebut tidak dilanjutkan untuk ke tahap yang selanjutnya. 


\section{c) Pelaksanaan program tahap II}

Pelaksanaan program tahap ini merupakan tahap pematangan setelah mengkonsep rencana persiapan pada tahap I. Sampai sejauh mana penetapan target sudah dilaksanakan. Pada tahap ini peran dari semua aktor tetap berfungsi. Pihak perusahaan yang ingin menampung hasil produksi keris, Kelompok UKM Pembuatan Keris Kabupaten Sumenep dan Pemerintah Kabupaten Sumenep pada tahap ini akan juga akan memberikan pelatihan berupa bagaimana cara memanage usaha, memberikan pelatihan, capacity building, menganalisa tantangan dan kendala internal dan eksternal pendirian usaha, dan strategi mempertahankan dalam kondisi krisis, dan menjalin kerjasama dengan UKM pembuatan keris di luar Kabupaten Sumenep guna memperluas pasar usaha mereka. Pelaksana program terfokus untuk mengembangkan program business plan-nya sesuai dengan visi misi usaha. program tahap II ini dilakukan selama 1 tahun setelah pelaksanaan tahap I. Pemerintah Kabupaten Sumenep juga bisa mengadakan Penyuluhan dan pendampingan Kewirausahaan bagi UKM pembuatan Keris Di Kabupaten Sumenep dengan maksud agar pelaku UKM pembuatan keris di Kabupaten Sumenep mampu dan memiliki pengetahuan dengan cara mengadopsi prinsip - prinsip kewirausahaan. Pada tahap ini Pemerintah Kabupaten Sumenep juga bisa mengadakan Diklat antara Kelompok UKM pembuatan Keris Kabupaten dan Siswa Kelas 1 dan Kelas 2 seluruh Sekolah Menengah Kejuruan (SMK) di Kabupaten Sumenep dalam peningkatan keterampilan produk pembuatan keris di Kabupaten Sumenep meliputi pengembangan dan pemanfaatan bahan baku lokal untuk membuat Keris.

Untuk meningkatkan pemahaman dan kepedulian pelaku usaha kecil akan pentingnya branding dan pengemasan, perlu dilakukan pelatihan (penyuluhan) kepada UMKM tentang pentingnya tampilan produk dan estetika pengemasan untuk meningkatkan branding produk. Bentuknya bisa berupa pelatihan desain produk. Selain itu, Kelompok UKM pembuatan Keris di kabupaten Sumenep juga perlu diberi kesempatan untuk menerapkan hasil pelatihan di lapangan untuk mempraktekkan teori melalui pengembangan kemitraan rintisan. Cara pandang Kelompok UKM pembuatan Keris di kabupaten Sumenep terhadap kemasan ataupun produk yang bernilai tambah perlu diubah. Perlu diberi pemahaman bahwa dengan kemasan yang baik, produk yang dijualkan akan menghasilkan keuntungan lebih besar karena bisa dijual dengan harga yang lebih tinggi.

\section{d) Monitoring dan evaluasi program tahap II}

Kegiatan evaluasi keberhasilan CSR merupakan hal yang sangat penting. Evaluasi pada tahap ini juga dilakukan untuk memonitor apakah program berjalan dengan baik atau tidak. Untuk mengetahui seberapa besar dampak positif yang dapat dirasakan oleh internal dari usaha tersebut dan masyarakat. Evaluasi pada tahap II ini dilakukan secara berkala dan dikerjakan langsung oleh oleh perusahaan dan tim monev. Mekanisme monev pada tahap ini tidak berbeda jauh dengan monev sebelumnya, yang membedakan hanya hasil yang akan dievaluasi. Monev ini akan menentukan program mana yang layak untuk dijadikan sebagai Rintisan kelompok UKM pembuatan Keris di Kabupaten Sumenep dari Pemerintah Kabupaten Sumenep. Rintisan UKM ini sebagai hasil dari rangkaian program pemerintah yang nantinya akan menjadi UKM pertama yang dikelola langsung oleh siswa Sekolah Menengah Kejuruan (SMK) setelah lulus sekolah, tenaga-tenaga SMK, sehingga lulusan SMK dapat berdaya dan tidak hanya 
menggantungkan pada lowongan kerja pada suatu perusahaan.

Dinas Koperasi, UKM, Perdagangan dan Perindustrian Kabupaten Sumenep juga memberikan bantuan modal berupa uang serta fasilitasi peralatan industri. Untuk bantuan modal berupa uang Dinas memberikan bantuan tersebut kepada pelaku industri kreatif kelompok pembuatan keris di Kabupaten Sumenep. Pemerintah Kabupaten Sumenep selalu mencarikan Informasi pasar yang lengkap dan akurat dapat dimanfaatkan oleh Kelompok UKM pembuatan keris Kabupaten Sumenep untuk membuat perencanaan usahanya secara tepat, misalnya : (1) membuat desain produk dan cara mengemasi produk keris yang disukai konsumen, (2) menentukan harga yang bersaing di pasar, (3) mengetahui pasar yang akan dituju, dan banyak manfaat lainnya. Oleh karena itu peran pemerintah sangat diperlukan dalam mendorong keberhasilan kelompok UKM pembuatan Keris di Kabupaten Sumenep dalam memperoleh akses untuk memperluas jaringan pemasarannya. Pemerintah Kabupaten Sumenep juga bisa mendirikan Pendirian Pusat Pengembangan Pendamping UKM (P3UKM) pembuatan keris di Kabupaten Sumenep, sebagai pilot project. P3UKM antara lain bertugas melakukan pelatihan dan akreditasi pendamping UKM pembuatan Keris di Kabupaten Sumenep

\section{Rintisan Kelompok UKM Pembuat Keris Kabupaten Sumenep sebagai hasil pelaksanaan program}

Setelah menjalan proses yang panjang maka berdasarkan laporan dan peninjauan Tim Monev dan perusahaan maka akan ditentukan program business plan dari siswa SMK yang layak untuk dijadikan Rintisan Kelompok UKM pembuatan Kabupaten Sumenep . program dari SMK ini merupakan percontohan, yang artinya program seperti ini akan dilaksanakan secara berkelanjutan sesuai dengan tujuan yang telah ditetapkan. Kelompok UKM pembuatan keris Kabupaten Sumenep ini masih dalam skala kecil karena masih terbentuk dan belum ditunjang permodalan yang memadai. Akan tetapi bukan berarti aktor yang telah melahirkan Kelompok UKM pembuatan Kabupaten Sumenep ini lepas tangan, justru dari terbentuknya ini maka peran dari Kelompok UKM pembuatan keris Kabupaten Sumenep dan perusahaan penampung hasil produksi keris akan lebih besar dalam membantu mengembangkan Rintisan Kelompok UKM pembuatan keris Kabupaten Sumenep ditengah iklim ekonomi yang tidak stabil. Tim pendamping Pemerintah Kabupaten Sumenep untuk Kelompok UKM pembuatan keris Kabupaten Sumenep tidak lagi mendampingi secara penuh seperti pada saat pelaksanaan program. Akan tetapi lebih menjadi partner dalam menjalankan usaha. Peran perusahaan penampung dan memasarkan produk hasil keris ini tentu akan lebih besar, dengan link yang dimiliki perusahaan akan sangat mendukung penentuan dan pengembangan perluasan pasar Rintisan Kelompok UKM pembuatan keris Kabupaten Sumenep.

Terbentuknya Rintisan Kelompok UKM pembuatan keris Kabupaten Sumenep hasil dari program pemerintah ini diharapkan mampu untuk dapat menyerap tenaga kerja dari Sekolah Menengah Kejuruan (SMK). program ini juga akan meningkatkan daya saing SMK terhadap persepsi masyarakat bahwa lulusan SMK mampu untuk memberikan kontribusi dalam pengurangan pengangguran dan mampu untuk membuka lapangan baru yang nantinya akan menyerap tenag-tenaga dari SMK.

Berikut Alternatif bentuk CSR yang ditawarkan oleh penulis untuk Kelompok UKM Pembuatan Keris di Kabupaten Sumenep adalah 
a) Pertama, CSR berbasis karikatif (charity). Program karikatif (charity) biasanya menjadi pijakan awal bagi sebuah perusahaan untuk melakukan program CSR. Program ini sifatnya murni amal. Program karikatif diwujudkan dengan memberikan bantuan yang diinginkan oleh masyarakat. Program karikatif yang bersifat pemberian (giving) sangat banyak kelemahannya antara lain: tidak bisa memberikan jaminan kesejahteraan dalam jangka waktu lama, masyarakat mempunyai kebiasaan mendapatkan hasil tanpa proses, jika dalam melakukan assessment tidak tepat justru bias memicu konflik horizontal yang sangat berbahaya. Program karikatif umumnya berwujud hibah sosial yang dilaksanakan untuk tujuan jangka pendek dan penyelesaian masalah sesaat saja.

b) Dalam dunia CSR, program kedermawanan (philanthropy) merupakan bentuk CSR yang didasari oleh kesadaran norma etika dan hukum universal akan perlunya redistribusi kekayaan. Program ini biasa dilakukan oleh orang-orang kaya dengan misi mengatasi masalah sampai ke akarnya. Program ini berwujud hibah untuk pembangunan baik infrastruktur maupun pembangunan SDM. Target program adalah masyarakat luas tidak hanya kaum miskin saja. Program ini terencana dengan baik dibuktikan dengan terbentuknya Yayasan independen yang menjadi agen perusahaan untuk melaksanakan program CSR Filantropinya.

Sifatnya yang lebih universal membuat program ini mempunyai efek yang lebih baik daripada program karikatif.

c) CSR berbentuk pemberdayaan masyarakat (community development). Salah satu implementasi tanggung jawab sosial perusahaan (corporate social responsibility) adalah melalui corporate citizenship. Corporate citizenship merupakan suatu cara pandang perusahaan dalam bersikap dan berperilaku ketika berhadapan dengan pihak lain, misalnya pelanggan, pemasok, masyarakat, pemerintah dan pemangku kepentingan (stakeholder) lainnya.

Pemasaran atau akses pasar. Mayoritas Kelompok UKM pembuatan Keris di Kabupaten Sumenep mengalami masalah lemahnya jaringan usaha dan kemampuan penetrasi pasar. Hal ini karena usaha kecil pembuatan keris di Kabupaten Sumenep umumnya merupakan unit usaha keluarga. Usaha pembuatan Keris di Kabupaten Sumenep misalnya, biasanya warisan turun temurun dari kakeknya, ayahnya kemudian ke anaknya. tidak ada strategi pemasaran jemput bola atau dengan memasarkan lewat online (internet). Strategi pemasaran yang dilakukan hanya dari mulut ke mulut. Pemasaran dilakukan dengan menunggu pembeli (pelanggan) dan kadangkala

\section{KESIMPULAN}

1. Hingga pertengahan 2014, angka pengangguran di Sumenep masih tinggi. Beberapa perusahaan maupun instansi pemerintahan belum bisa menyerap tenaga kerja secara memadai. Terbukti, jumlah pengangguran hingga sekarang mencapai 23.618 jiwa. Data Dinas Tenaga Kerja dan Transmigrasi (Disnakertrans), dari 40.762 jiwa pencari kerja (pencaker), yang terserap hingga Juli 2014 hanya sebanyak 17.144 jiwa. Jadi, masih tersisa 57,94 persen pencaker yang masih menganggur. Faktor terbesar yang menyebabkan 
angka pengangguran meningkat di Sumenep, kata dia, karena banyaknya lulusan dari lembaga pendidikan, baik SMA maupun perguruan tinggi. Persoalan pengangguran itu tugas yang cukup berat dan tidak mudah dalam mengentaskannya seperti membalikkan telapak tangan. Butuh proses panjang dan keterlibatan semua elemen masyarakat, Persoalan terbesar kebangkitan ekonomi adalah banyaknya pengangguran, dan untuk Kabupaten Sumenep, angka pengangguran terbuka masih bertengger di angka 30.000 dari jumlah total penduduk lebih dari 1 juta jiwa. Meski ada angka penurunan, namun tidak begitu signifikan.

Pemerintah Kabupaten Sumenep tidak hanya sebatas menyebarkan brosur tentang kegiatan masing-masing kejuruan yang ada di SMKN maupun SMK Swasta di Kabupaten Sumenep, namun akan terus melakukan sosialisasi langsung ke masyarakat dan tempattempat unit usaha yang nantinya perlu tenaga teknik dan membantu berwirausaha dengan para Kelompok UKM pembuatan keris di Kabupaten Sumenep yang sesuai dengan keahlian para lulusannya. selama ini perkembangan SMK Negeri I Sumenep dan SMKN I Kalinaget kurang mendapat respon dari masyarakat.

2. Pada umumnya perkembangan SMK di Kabupaten Sumenep sudah mengalami peningkatan yang sangat pesat. Berbagai fasilitas penunjang belajar banyak diberikan oleh Dinas Pendidikan Kota Surabaya untuk Sekolah Menengah Kejuruan (SMK) ini dikarenakan pemerintah ingin lebih mengembangkan SMK daripada SMA. guna memenuhi keinginan pembangunan sekolah kejuruan tidak perlu membangun unit sekolah baru. Tapi untuk pengembangan sejumlah bidang keahlian yang sesuai dengan potensi lokal di SMK Negeri I Sumenep dan SMK Negeri I Kalianget, guna memenuhi keinginan pembangunan sekolah kejuruan tidak perlu membangun unit sekolah baru. Tapi untuk pengembangan sejumlah bidang keahlian yang sesuai dengan potensi lokal di SMK Negeri I Sumenep dan SMK Negeri I Kalianget, Hal itu disebabkan lulusan SMK dianggap lebih produktif dan memiliki kemampuan lebih untuk masuk dunia kerja. seiring perkembangannya ternyata tidak diimbangi dengan kompetensi pendidikan dasar yang dimiliki oleh masing-masing sekolah, terbukti dengan banyaknya pembengkakan jurusan. Sehingga mengakibatkan sekolah tidak mempunyai spesifikasi khusus keahlian.

3. Terdapat lima langkah dalam pelaksaan penerapan CSR ini, langkah-langkahnya dimulai dengan Pembentukan program oleh pemerintah Kabupaten Sumenep untuk siswa SMK ada dua berupa business plan competition menggandeng Kelompok UKM pembuatan Keris Di kabupaten Sumenep. Selanjutnya adalah tahap sosialisasi ke tiap-tiap SMK mengenai program yang dicanangkan pemerintah.Kabupaten Sumenep dalam pelaksanaannya nanti setelah melewati tahap seleksi proposal bagi Kelompok UKM pembuatan Keris yang mengajukan proposal dan pendataan jumlah siswa yang akan di arahkan dan di fokuskan untuk membantu Kelompok UKM pembuatan Keris di Kabupaten Sumenep. pendampingan oleh Kelompok UKM pembuatan Keris di Kabupaten Sumenep langsung serta kontrol dari pemerintah dilakukan guna kelancaran program ini. sehingga nantinya dapat 
menghasilkan ouput berupa hasil didikan program pengembangan kewirausahaan sebagai bentuk awal atau perintis kelompok UKM Pembuatan Keris di Kabupaten Sumenep.

\section{SARAN}

1. Sinergitas yang berkelanjutan antar aktor sangat dibutuhan untuk menekan angka pengangguran di Kabupaten Sumenep dan membangkitkan Ketrampilan dalam pembuatan Keris bagi Masyarakat Lokal di Kabupaten Sumenep.

2. Program ini merupakan proyek percontohan SMK di Kabupaten Sumenep dan dapat untuk diterapkan pada daerah lain. Akan tetapi harus disesuaikan dengan kondisi dan karakteristik daerah tersebut. Hal ini disebabkan karakteristik masyarakat suatu daerah belum tentu sama dengan daerah yang lain.

\section{UCAPAN TERIMAKASIH}

Penulis menyadari bahwa penyusunan penulisan ini tidak akan terwujud tanpa adanya bantuan dan dorongan dari berbagai pihak. Oleh karena itu, pada kesempatan ini penulis ingin menyampaikan ucapan terima kasih kepada yang terhormat :

1. Ibu Dra. Dewi Amartani. M.Si selaku Dekan Fakultas IImu Sosial dan IImu Politik Universitas Bhayangkara Surabaya memberikan ilmu serta arahan dan motivasi untuk segera menyelesaikan penulisan ini.

2. Bapak Drs. Herman Moeis. M.Si selaku Kepala Program Studi Administrasi Publik Universitas Bhayangkara Surabaya memberikan ilmu serta arahan dan motivasi dalam proses penyelesaian penulisan ini.

\section{DAFTAR PUSTAKA}

Budiraharjo,Eko. 1997. Arsitektur dan Kota di Indonesia. Bandung: PT ALUMNI

Foley G. 1993.Pemanasan global, Jakarta. Yayasan Obosi Ind,

Heddy,suwasono dkk.1986. Pengantar Ekologi. Jakarta. CV Rajawali

Soegijanto.1999. Bangunan di Indonesia Dengan Iklim Tropis Lembab ditinjau dari Aspek Fisika Bangunan. Departemen Pendidikan dan Kebudayaan:Jakarta

\section{Internet:}

Anonim.2008.Pemanasan

Global.Wikipedia.org.tanggal akses 24 April 2008

Anonim.2008.Seruan Green Building para Arsitektur.republikaonline.com tanggal akses 24 April 2008.

Anonim.2008. Para Pakar Green House suarasurabaya.net tanggal akses 24 April 2008.

Anonim.2008.pemanasan global dan green building .www.tabloidnova.com tanggal akses 24 April 2008

Anonim.

2007.emisi karbon.www.futurearc.com.tanggal akses 24 April 2008

El, Ant.2007. Dampak Global Warning di Indonesia. www.gatraonline.com tanggal akses 24 April 2008.

Raharjo. 2007. pencemaran udara. www.ns.doe.ca/udo/pics/warm14. tanggal akses 24 April 2008.

http://www.lontarmadura.com/ Ditayangkan: 12-07-2012 Oleh : RB. Ahmad Ramadan

Konsepsi Keris dalam Budaya Masyarakat Madura

http://www.beritametro.co.id/ Miliki Empu Terbanyak Se-Asia Tenggara Kamis, 14 November 2013 00:11 
http://sumenepkab.go.id/ SMK Negeri 1

Kalianget Kembangkan Jalinan Kemitraan [ Jum'at, 18 Pebruari 2011 pukul 15:38 wib http://www.sumenep.go.id/ Masih Perlu Pertimbangan, Untuk Membangun SMK Baru Kamis, 8 Juli 2010 pukul 16:05 wib. 